Wrocław University of Economics

\title{
Changes in Demand and Expenses for Food in Households in Poland
}

\begin{abstract}
The aim of the work is to assess the demand for food among households in Poland and the changes that occurred in this demand in the years 2000-2016. In addition, changes in the consumption of selected food products over a period of 10 years depending on the socio-economic group of the household have been evaluated. The research material consists of secondary data obtained from the publication of the Central Statistical Office in the years 2000-2016. The study uses descriptive statistics methods. The income situation of households in Poland during the period under review significantly improved. In the analysed years, monthly expenses on food products per one person grew slower than total expenditure and disposable income. The analysis of the research material showed a decrease in consumption of the majority of discussed food products. The increase in demand occurred in the case of yoghurts as well as cheese and curd. The analysis divided into socio-economic groups of the households showed significant variation in the consumption of sugar, fish and seafood as well as oils and fats.
\end{abstract}

Key words: consumption, expenses, households, foodstuffs

JEL Classification: D1, D3, E21, E24

\section{Introduction}

Today, there are changes in all areas of life in the world. The globalization of economies, the growing exchange of information and social contacts contribute to changes in behaviour, attitude, hierarchy of values or the way of work that affect the way people live and nourish themselves (Regmi, 2001; Senauer, 2001; Blisard et al., 2002; Cromartie, 2002; Goryńska-Goldmann, 2010). The changes in eating habits of the population are influenced, among others, by growing awareness or so-called "fashion" for healthy eating and a healthy lifestyle, which results in an increase in interest in food perceived as healthy. Food is a source of nutrients for a man, thanks to which his health and life are not endangered. Subject matters showing the demand for food among Polish residents and the directions of changes in the consumption of individual food products are important and always valid from a cognitive point of view. In Poland, similarly to other developed countries, there are visible changes in the diet of the residents. Households are moving away from preparing meals at homes in favour of dining at catering establishments.

Food consumption is a topic often discussed in scientific literature. The issues of household demand for food in Poland have been addressed by numerous authors in their works (i.a. Świetlik, 2015; Laskowski, 2008; Bywalec, 2010; Urban, Tarnowska, 2012). Its significance for the functioning of the human body is, certainly, not without significance for the state of affairs. Over the years, patterns have changed with regard to the way of eating and its impact on human

\footnotetext{
${ }^{1}$ dr inż., ul. Komandorska 118/120, 53-345 Wrocław, e-mail: anna.kowalska@ue.wroc.pl; https://orcid.org/0000-0002-8472-8386
} 
health and life. Our incomes are one of the factors influencing the way we eat. Zalega (2008) among the factors determining the economic availability of food, and thus shaping its consumption, lists, in addition to the aforementioned income, also the prices of food products. Consumer habits are also an important issue.

The trends of food consumption (availability) and forecasts by 2050, both for the whole world and for particular regions, have shown changes in dietary patterns in the world in the consumption of basic products. The analysis shows that the changes are moving towards more varied diet. These changes are dictated by i.a. unfavourable changes in consumption visible for many years, both at the global and regional levels. These changes had serious health consequences for the residents. For years it can be heard about health problems associated with improper consumption of products, which leads to overweight and obesity (Kearney, 2010) The phenomenon of increasing overweight and obesity is visible especially in highly developed countries. In France, obesity and overweight have been increasing since the nineties. According to the 2003 study on health in the years 1980-2003, the percentage of overweight people increased from $32.9 \%$ to $37.5 \%$, and in the case of obesity, from $6.3 \%$ to $9.9 \%$ (Paraponaris et al., 2005). In the United States, overweight and obesity is a big problem as well. This is evident in the costs of medical treatment for people with obesity, which in 2003 amounted to about 75 billion dollars and were higher than for the treatment of smokers (Grossman \& Rashad, 2004). Unfavourable changes in the consumption of food products are also visible in other European countries (Varela-Moreiras, et al., 2010; Whitton, et al., 2011). According to the data of the World Food Safety Index, obesity concerns already $23.2 \%$ of the population living in Poland. The same percentage of obese people may be observed in Norway, and slightly lower in i.a. Russia (23.1\%), Belarus (22.2\%) and Hungary (22\%). In Europe, the majority of obese people may be found in the UK (27.3\%), Ireland (25.5\%) and the Czech Republic (23.8\%). In 2017, over $64 \%$ of men and $49 \%$ of women in Poland were overweight (www.rynekzdrowia.pl). Such state of affairs is determined by multiple factors, including eating highly processed food and catering at fast food restaurants.

Governments of richer countries use fiscal measures to fight overweight and obesity, which changes the relative price of food, to promote healthy products (Smed, 2012; Holt, 2011). According to research, the imposition of taxes on food, i.e. sweetened beverages or foods rich in saturated fat or salt, may contribute to the reduction of obesity and mortality of the population from cardiovascular causes (Andreyeva et al, 2011; Dharmasena \& Capps, 2011; Mytton, et al, 2007; Allais, et al, 2010; Green, et al., 2013). Kearney (2010) believes that the future food policy must take into account both the agricultural and health sectors, thus enabling the development of coherent and sustainable policies that will ultimately benefit agriculture, the health of people and the environment.

The aim of the work was to assess the demand for food of households in Poland and the changes that occurred in this demand in the years 2000-2016. In addition, the subject of consideration was the assessment of changes that occurred in the consumption of selected food products depending on the socio-economic group of households.

\section{Data and methods}

The paper uses secondary data published by the Central Statistical Office regarding expenditures and consumption of selected food products by households in Poland. The time range of analyses covered the years 2000-2016 and was intended to show the changes that 
took place both in the case of expenditure and the consumption of selected food products (the author realizes that some data may not be comparable due to changes made by the Central Statistical Office in publications at the turn of the period). Data analysis was made using descriptive statistics methods such as: location, variability and dynamics. The linear regression model was also used. Consumption measures (Bywalec and Rudnicki, 1999) used in the study included:

- expenditure and consumption dynamics of selected food products (i.e. individual chain indices),

- average level of consumption (i.e. average monthly consumption of food products per person),

- consumption structure (i.e. the share of expenditure on food in total expenditure and the share of consumption of particular groups of food products in total food consumption).

The analysis was made both in terms of the amount and value of the products consumed. The work also calculates the classic coefficient of variation (1) in order to show the variation in expenditure on food products, as well as in the consumption of individual food products depending on the socio-economic group of the household.

$$
V=\frac{s}{\bar{x}} \times 100 \%
$$

Where:

$\mathrm{s}$ - standard deviation,

$\bar{x}-$ arithmetic mean.

\section{Expenditure and consumption of selected food products in households in the years 2000-2016}

Figure 1 presents the level and dynamics of changes in disposable income, total expenditure and expenses on food and non-alcoholic beverages in Polish households in the years $2000-2016$.

In Poland, the improvement of the financial situation of households is visible. In 2016, households had real disposable income - PLN 1483.46/person, which increased (compared to 2015) by $6.6 \%$, while in 2015 (compared to 2014) it increased by only $4.3 \%$. Certainly, one of the reasons for the increase in household incomes was the Rodzina 500+ program, launched from April 1, 2016. According to CSO data, benefits obtained under this program (in the families receiving them) constituted on average $16.8 \%$ of disposable income per person (results for the second and fourth quarters of 2016), (Sytuacja gospodarstw..., 2017). In the years 2000-2016 real total expenditures per person would grow at a slower pace than the real disposable income. In the audited period, real disposable income per one person increased by more than PLN 59.3 annually $\left(\mathrm{R}^{2}=0.99\right)$, while real total expenses increased by over PLN $39.1\left(\mathrm{R}^{2}=0.98\right)$. Real expenditures on food and non-alcoholic beverages grew at much slower rate during the period under consideration (annually, per person on average by almost PLN 7) than real total expenditures and in 2016 amounted to PLN 274.1 (an increase compared to 2000 at the level of 64\%). Increasing real household income was visible in higher real total expenditure and expenses for food products of these households, which in 2016 amounted to PLN 1133.5/person and were higher by 3.4\% as compared to 
2015 and by $109.1 \%$ higher in relation to 2000 . The share of total expenditure per person in 2016 was $76.7 \%$ of income, while in 2000 it was almost $98.2 \%$ (decrease of share by 21.4 $\mathrm{pp}$ ). The declining trend was also visible in the case of the share of expenditures on food and non-alcoholic beverages in relation to the total expenditure incurred per 1 person in the household. In the years $2000-2016$, it decreased by 6.6 pp (from $30.8 \%$ in 2000 to $24.2 \%$ in 2016) The declining share of total expenditure and food expenses may indicate that this difference is allocated to the purchase of other goods for household purposes, e.g. home appliances, car goods, or savings on bank accounts.
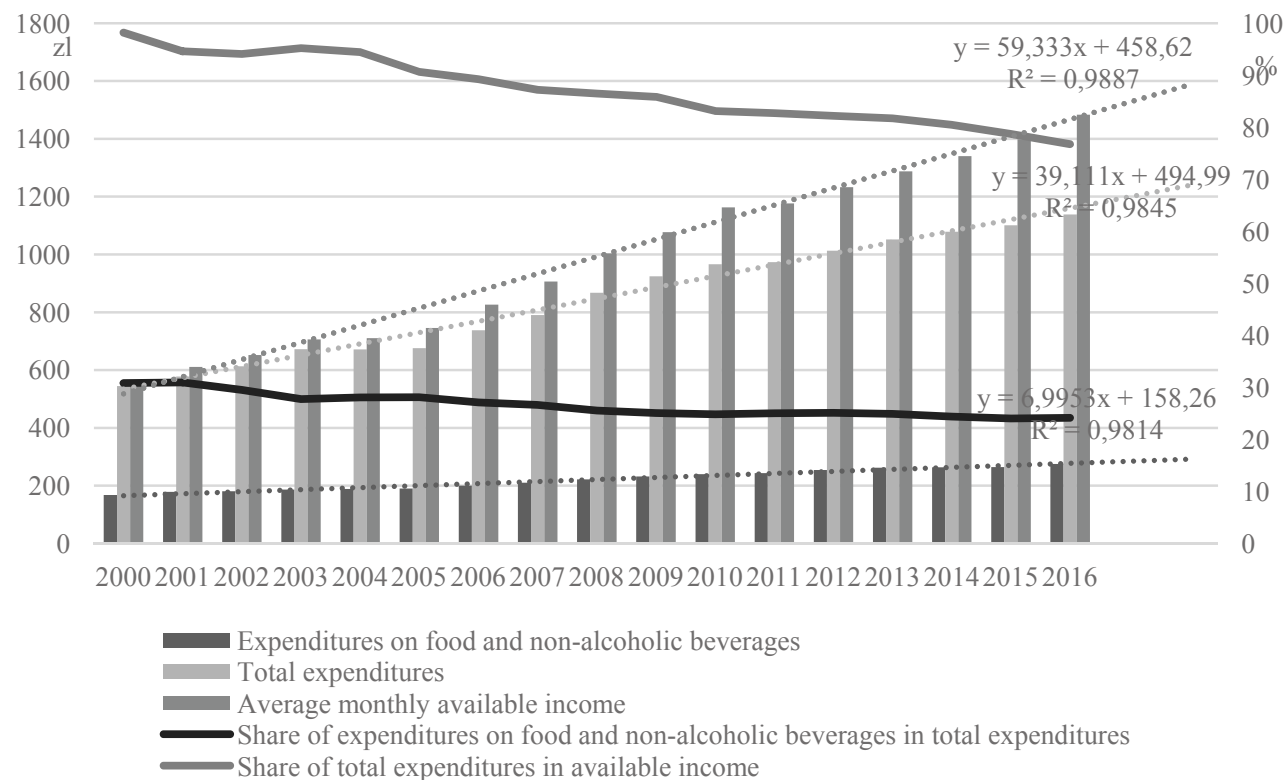

Fig.1. Changes in the intersecting monthly real disposable income and expenses per person in Polish households in the years $2000-2016(2000=100)$

Source: (Rocznik Statystyczny... 2001-2017), own calculations.

The average monthly consumption of selected food products per 1 person in a household in the years 2000-2016 is shown in Table 1. In the analysed years, the consumption per person of the majority of analysed food products decreased in Poland, with the exception of yoghurts as well as cheese and curd which showed an upward trend.

The highest average annual decreases in food consumption in the analysed period (at $\mathrm{R}^{2} \geq 0.9$ ) concerned: vegetables (by $0.32 \mathrm{~kg}$ ), eggs (by more than $0.23 \mathrm{pc}$ ), bread (by 0.2 $\mathrm{kg}$ ) and milk (by $0.14 \mathrm{l}$ ). Certainly, limiting by residents the consumption of such products as bread, sugar, oils and fats is positively evaluated from a nutritional point of view. However, the worrying trend is the limitation of consumption of products that are equally important from the nutritional point of view, i.e. vegetables, fruit, as well as eggs and fish. These products contain nutrients necessary for the proper functioning of the body. 
Table 1. Average monthly consumption of selected food products per 1 person in households in the years 2000$2016(\mathrm{~kg}, 1, \mathrm{pcs})$

\begin{tabular}{|c|c|c|c|c|c|c|c|c|c|c|c|c|c|c|c|c|c|c|c|}
\hline $\begin{array}{c}\text { Specificati } \\
\text { on }\end{array}$ & 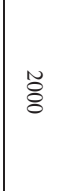 & 苂 & 苍 & 芯 & 苍 & 荅 & 苂 & 苂 & 苚 & 䓍 & 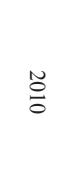 & $\stackrel{N}{\varrho}$ & $\stackrel{\text { O }}{\stackrel{N}{N}}$ & 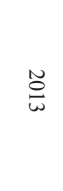 & $\stackrel{\stackrel{N}{O}}{\square}$ & 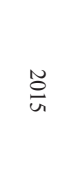 & 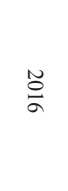 & 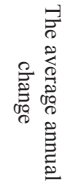 & 必 \\
\hline Bread (kg) & 6.61 & 6.55 & 6.33 & 6.17 & 6.08 & 5.90 & 5.57 & 5.29 & 5.06 & 4.85 & 4.67 & 4.46 & 4.38 & 4.13 & 3.94 & 3.74 & 3.52 & -0.201 & .99 \\
\hline Meat $(\mathrm{kg})$ & 5.47 & 5.39 & 5.41 & 5.59 & 5.43 & 5.48 & 5.40 & 5.39 & 5.60 & 5.65 & 5.57 & 5.48 & 5.42 & 5.26 & 5.29 & 5.27 & 5.32 & -0.008 & 0.13 \\
\hline Fish (kg) & 0.43 & 0.42 & 0.40 & 0.41 & 0.41 & 0.42 & 0.42 & 0.45 & 0.47 & 0.46 & 0.45 & 0.43 & 0.42 & 0.34 & 0.33 & 0.33 & 0.32 & -0.005 & 0.28 \\
\hline Milk (1) & 5.39 & 5.11 & 4.89 & 4.89 & 4.60 & 4.43 & 4.12 & 3.84 & 3.64 & 3.51 & 3.51 & 3.42 & 3.41 & 3.35 & 3.26 & 3.15 & 3.08 & -0.144 & 0.93 \\
\hline Cheese (kg) & 0.83 & 0.84 & 0.84 & 0.89 & 0.87 & 0.87 & 0.89 & 0.88 & 0.88 & 0.92 & 0.95 & 0.94 & 0.95 & 0.83 & 0.82 & 0.83 & 0.85 & 0.001 & 0.02 \\
\hline Yoghurts (1) & 0.33 & 0.32 & 0.33 & 0.36 & 0.35 & 0.34 & 0.37 & 0.44 & 0.46 & 0.47 & 0.54 & 0.54 & 0.52 & 0.51 & 0.50 & 0.50 & 0.53 & 0.015 & 0.84 \\
\hline Eggs (pcs) & 14.62 & 14.79 & 15.08 & 15.16 & 14.89 & 15.16 & 14.02 & 13.49 & 13.05 & 13.00 & 12.81 & 12.54 & 12.5 & 12.17 & 12.02 & 11.76 & 11.64 & -0.230 & 0.90 \\
\hline $\begin{array}{l}\text { Oils and } \\
\text { fats }(\mathrm{kg})\end{array}$ & 1.56 & 1.59 & 1.58 & 1.61 & 1.57 & 1.53 & 1.46 & 1.42 & 1.39 & 1.37 & 1.35 & 1.31 & 1.31 & 1.23 & 1.21 & 1.15 & 1.13 & -0.030 & 0.96 \\
\hline $\begin{array}{l}\text { Vegetables } \\
\quad(\mathrm{kg})\end{array}$ & 13.27 & 12.85 & 13.02 & 12.67 & 12.33 & 12.44 & 11.06 & 10.77 & 10.51 & 10.28 & 9.95 & 9.88 & 9.60 & 9.03 & 8.99 & 8.68 & 8.59 & -0.316 & 0.97 \\
\hline Fruit (kg) & 4.10 & 4.08 & 4.07 & 3.99 & 3.91 & 3.72 & 3.55 & 3.40 & 3.59 & 3.77 & 3.43 & 3.29 & 3.45 & 3.43 & 3.59 & 3.59 & 3.66 & -0.036 & 0.53 \\
\hline Sugar (kg) & 1.80 & 1.76 & 1.70 & 1.69 & 1.62 & 1.53 & 1.51 & 1.42 & 1.41 & 1.38 & 1.30 & 1.18 & 1.2 & 1.17 & 1.19 & 1.09 & 1.01 & -0.048 & 0.98 \\
\hline $\begin{array}{c}\text { he amount of } \\
\text { food } \\
\text { consumed } \\
(\mathrm{kg})\end{array}$ & 40.80 & 39.92 & 39.59 & 39.30 & 38.18 & 37.68 & 35.30 & 34.22 & 33.90 & 33.54 & 32.60 & 31.79 & 31.52 & 30.12 & 29.94 & 29.14 & 28.81 & -0.836 & 0.98 \\
\hline
\end{tabular}

Source: (Rocznik Statystyczny... 2001-2017), own calculations.

The amount of purchased and consumed food per person was also analysed. In the analysed period, there was a visible decrease in the quantity of consumed products. In 2000 , the average amount of food consumed per person (this applies to the food products in question) was over $40 \mathrm{~kg} /$ month. In 2016, this amount decreased by almost 12 $\mathrm{kg} /$ person/month and amounted to less than $30 \mathrm{~kg}$. The analysis of the trend line showed that the amount of food consumed was systematically decreasing over the entire analysed period, on average by $0.84 \mathrm{~kg}$ (with $\mathrm{R}^{2}=0.98$ ). Such a good adjustment of the trend line may suggest a further decrease in the amount of consumed products.

\section{Expenditure of households on selected food products and their consumption divided into socio-economic groups in 2006 and 2016}

The average monthly expenditure on selected food products and their consumption per person in households by socio-economic groups in 2006 and 2016 is presented in Table 2.

\footnotetext{
${ }^{2}$ It was assumed that weight: eggs $(\mathrm{pcs})=0.056 \mathrm{~kg}$, milk (liter) $=1.029 \mathrm{~kg}$, yoghurt $($ liter $)=1.111 \mathrm{~kg}$.
} 
According to the analysis of expenditures, the highest variation in 2016 in particular socioeconomic groups of households characterized expenditure on the following products and product groups: sugar $(\mathrm{V}=31.7 \%)$, oils and fats $(\mathrm{V}=21.4 \%)$, eggs $(\mathrm{V}=20.7 \%)$ and fruit $(\mathrm{V}$ $=20.7 \%)$. The smallest value of the coefficient of variation was recorded in the case of expenditure on: meat $(\mathrm{V}=14.2 \%)$, vegetables $(\mathrm{V}=14.6 \%)$ and bread $(\mathrm{V}=14.9 \%)$. Comparing the coefficients of variation of expenditures in individual product groups in 2006 and 2016, there was a significant reduction in the variation of expenditures incurred in individual groups of households for yoghurts (by $16.3 \mathrm{pp}$ ) as well as fish and seafood. On the other hand, the expenditure diversification in particular households increased in the case of sugar. In the case of consumption of selected food products, the highest variation in 2016 was recorded for: sugar $(\mathrm{V}=34.1 \%)$, oils and fats $(\mathrm{V}=23.2 \%)$, fish and seafood $(\mathrm{V}=23.2 \%)$, vegetables $(\mathrm{V}=20.8 \%)$, bread $(\mathrm{V}=20.1 \%)$ and eggs $(\mathrm{V}=20.0 \%)$.

Table 2 . Average monthly expenditures on selected food products and their consumption per one person by socio-economic groups in 2006 and $2016(\mathrm{~kg}, 1, \mathrm{PLN}, \%)$

\begin{tabular}{|c|c|c|c|c|c|c|c|c|c|c|c|c|c|c|c|c|c|}
\hline \multirow{4}{*}{ Specification } & \multicolumn{15}{|c|}{ Type of household according to socio-economic groups } & \multirow{3}{*}{\multicolumn{2}{|c|}{$\begin{array}{c}\begin{array}{c}\text { Coefficient } \\
\text { of variation } \\
\text { V }(\%)\end{array} \\
\text { years }\end{array}$}} \\
\hline & \multicolumn{3}{|c|}{ employees } & \multicolumn{3}{|c|}{ farmers } & \multicolumn{3}{|c|}{ self-employed } & \multicolumn{3}{|c|}{ retirees } & \multicolumn{3}{|c|}{ pensioners } & & \\
\hline & \multicolumn{2}{|c|}{ years } & \multirow{2}{*}{\begin{tabular}{|c|} 
Change \\
$(\mathbf{\%})^{*}$
\end{tabular}} & \multicolumn{2}{|c|}{ years } & \multirow{2}{*}{$\begin{array}{c}\text { Change } \\
(\%)^{*}\end{array}$} & \multicolumn{2}{|c|}{ years } & \multirow{2}{*}{\begin{tabular}{|c|}
$\begin{array}{c}\text { Change } \\
(\mathbf{\%})^{*}\end{array}$ \\
\end{tabular}} & \multicolumn{2}{|c|}{ years } & \multirow{2}{*}{$\begin{array}{l}\text { Change } \\
(\%)^{*}\end{array}$} & \multicolumn{2}{|c|}{ years } & \multirow{2}{*}{\begin{tabular}{|c|} 
Change \\
$(\%)^{*}$
\end{tabular}} & & \\
\hline & 2006 & 2016 & & 2006 & 2016 & & 2006 & 2016 & & 2006 & 2016 & & 2006 & 2016 & & 2006 & 2016 \\
\hline Breac & 15.20 & 16.86 & 10.92 & 17.75 & 20.70 & 16.62 & 14.34 & 15.50 & 8.09 & 18.24 & 21.61 & 18.48 & 18.52 & 21.62 & 16.74 & 11.34 & 14.93 \\
\hline Mc & 50.03 & 64.63 & 29.18 & 66.10 & 76.54 & 15.79 & 56.72 & 65.99 & 16.34 & 68.09 & 90.00 & 32.18 & 7.06 & 82.26 & 4.16 & 46 & 4.2 \\
\hline Fis & 24 & 8.25 & 57. & 4.46 & 7.27 & 63.00 & 6.86 & 0.11 & 47.38 & 8.23 & 12.13 & 47.39 & 6.02 & 9.88 & & & \\
\hline \begin{tabular}{l|l} 
if & $\mathrm{Mil}$
\end{tabular} & 5.83 & 6.03 & 3.43 & 9.03 & 8.54 & -5.43 & 41 & 85 & -8.74 & 8.78 & 8.09 & -7.86 & 15 & 8.17 & 25 & 83 & 7.55 \\
\hline Chees & 3.29 & 3.82 & $\begin{array}{ll}2 & 16.11\end{array}$ & 1.67 & 2.70 & 61.68 & 4.43 & 4.25 & -4.06 & 3.78 & 3.78 & 0.00 & 2.82 & 3.37 & 19.50 & 2.58 & 16.3 \\
\hline Yog & 10.40 & 12.97 & $7 \quad 24.71$ & 8.21 & 9.65 & 17.54 & 12.53 & 140 & 16.60 & 2.20 & 15.44 & $\begin{array}{ll}4 & 26.56\end{array}$ & 0.25 & 13.54 & & 22 & 16.7 \\
\hline Egg & 4.15 & 5.35 & $5 \quad 28$ & 6.08 & 8.25 & 35.69 & 4.30 & 5.42 & 26.05 & 5.99 & 8.08 & & 5.46 & 7.59 & & 69 & .13 \\
\hline Oils & 8.58 & 9.74 & $\begin{array}{l}4 \\
+\end{array}$ & 9.65 & 10.46 & 8.39 & 9.73 & & 8.12 & 13.51 & 15.73 & $3 \quad 16.43$ & .63 & 13.75 & 23 & .40 & 21.43 \\
\hline & 10.28 & 16.50 & 6 & 2 & & & & & 16 & 73 & & & 89 & & & & 20.7 \\
\hline Fru & 20.98 & 28.31 & $\begin{array}{l}1 \\
1\end{array} 4.94$ & 22.94 & 26.25 & 14.43 & 23.21 & 30. & & 9.63 & 37.46 & 26.43 & 26.01 & 34.73 & & 67 & 14.6 \\
\hline Sug & 3.75 & 2.46 & $5 \quad-34.40$ & 6.50 & 4.68 & -28.00 & 3.51 & 2.15 & -38.75 & 6.13 & 3.98 & $\begin{array}{ll}8 & -35.07\end{array}$ & 65 & 4.06 & 8.14 & 12 & 31.72 \\
\hline & & & $4-3$ & & & -3 & & & & & & & & & & & 20.08 \\
\hline & 4.82 & 4.79 & -0. & 6.88 & 6.21 & -9.74 & 4.97 & 4 & -9.46 & 6.60 & .88 & 4 & 99 & 6.76 & $\begin{array}{l}5 \\
5\end{array}$ & 93 & 19.1 \\
\hline Fish & 0.37 & 0.28 & $\begin{array}{ll}3 & -24.32\end{array}$ & 0.36 & 0.31 & -13.89 & 0.45 & 0.31 & -31.11 & 0.61 & 0.48 & $\begin{array}{ll}3 & -21.31\end{array}$ & 0.46 & 0.40 & -13.04 & 22.28 & 23.21 \\
\hline Milk & 3.42 & 2.80 & -18.13 & 6.41 & 4.09 & -36 & 3.56 & & -25.84 & 5.23 & 3.68 & & 4.90 & 3.73 & & & 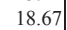 \\
\hline $\mathrm{Che}$ & 0.38 & 0.54 & $4 \quad 42$. & 0.22 & 0.38 & 72 & 0.47 & 0.58 & & 0.39 & 0.55 & $5 \quad 41$ & 0.30 & 0.50 & 66.67 & & 15. \\
\hline Yoghu & 0.85 & 0.82 & $2 \quad-3.53$ & 0.76 & 0.67 & -11.84 & 0.97 & 0.87 & -10.31 & 1.06 & 1.03 & -2.83 & 0.90 & 0.93 & 3.33 & 59 & 15.48 \\
\hline Eggs & 12.41 & 10.32 & $2-16.84$ & 17.11 & 14.30 & -16.42 & 12.51 & 9.93 & -20.62 & 17.41 & 15.17 & $\begin{array}{lll}7 & -12.87\end{array}$ & 16.24 & 14.97 & -7.82 & 39 & 20.03 \\
\hline & & 1.01 & $1-21$. & & & -22 & & & -26 & 1.88 & & $3-18.62$ & 1.82 & & & & \\
\hline & 3.18 & 3.34 & 5. & & 3.16 & -12 & 3.79 & & -1.06 & 4.67 & 4.90 & 4.93 & 3.65 & 4.16 & & & 18 \\
\hline Fru & 3 & 7.62 & $\begin{array}{ll}\mid-19.19\end{array}$ & 14 & 10.53 & -26 & 9. & & -20 & 14.62 & 11.26 & $\begin{array}{ll}6 & -22.98\end{array}$ & 13.45 & 11.25 & & & 20.7 \\
\hline $\mathrm{Su}$ & 1.26 & 0.85 & & & & 20 & 1.16 & 0.70 & & 2.02 & & & 1.87 & 42 & & 20.62 & 34.1 \\
\hline $\begin{array}{l}\text { The amount o } \\
\text { food } \\
\text { consumed }(\mathrm{kg}\end{array}$ & 30.98 & 26.01 & 97 & 44.14 & 33 & -1 & 31.16 & 25.0 & -6.1 & 44.43 & 36 & $-7.51^{\mid}$ & 41.00 & 36.13 & -4 & & \\
\hline
\end{tabular}

Source: (Budżety ... 2006, 2016), own calculations, ${ }^{*}$ Change $=\frac{\text { year } 2016-\text { year } 2006}{\text { year } 2006} \times 100 \%,{ }^{1}-$ in $\mathrm{kg}$.

The lowest, however, it was in the case of cheese and curd $(\mathrm{V}=15,5 \%)$ and yoghurts $(\mathrm{V}=15.3 \%)$. A comparison of the coefficients of variation in 2006 and 2016 showed that the diversification of consumption between particular groups of households in the case of yoghurt and milk decreased significantly. On the other hand, it increased in the case of sugar. In 2016, as in 2006, meat, bread and cereal products, vegetables and fruit accounted for nearly $60 \%$ of all expenses incurred on food products per person monthly.

The analysis of individual socio-economic groups has shown that retired people are the group of people who consume and spend the most for the abovementioned food 
products. In 2016, in pensioners' households, monthly meat expenses amounted to PLN 90/person, with an average consumption of meat at the level of almost $7 \mathrm{~kg}$ in these households. At the same time, expenditures for this purpose in the households of selfemployed were by PLN 24 and in the households of employees by PLN 25.4 lower.

The average expenditure in 2016 incurred by pensioners' households for meat was PLN $13.1 / \mathrm{kg}$ and in comparison to 2006 it increased by almost $26.8 \%$.

In 2016, the group that tended to spend the most for a kilogram of meat were the households of self-employed (14.7 PLN/kg), while the least paid the pensioners (12.2 PLN/kg). In 2016, from among the socio-economic groups discussed pensioners also bought and consumed the biggest quantities of: fish and seafood, cheese and curd, eggs, oils and fats, vegetables and fruit. In these household, the expenses per $\mathrm{kg}$ or a piece of product were on an average level (compared to other groups of households) and amounted

in case of fish and seafood to PLN $25.3 / \mathrm{kg}$, cheese and curd about PLN 15/kg, eggs 0.5 PLN/pc, oils and fats $-10.3 \mathrm{PLN} / \mathrm{kg}$, vegetables - 3.3 PLN $/ \mathrm{kg}$ and fruit $4.7 \mathrm{PLN} / \mathrm{kg}$. The highest expenses per a $\mathrm{kg}$ or a litre of these products (excluding eggs) used to incur the households of self-employer persons. In the case of these households, the average expenditure for a $\mathrm{kg}$ or a litre of a product was, for example, in the case of cheese and curd - 16,8 PLN/kg, meat - 14.7 PLN/kg, fish and seafood - 32.6 PLN/kg, oils and fat - 11.6 $\mathrm{PLN} / \mathrm{kg}$, fruit $-5,4 \mathrm{PLN} / \mathrm{kg}$, vegetables - $4.22 \mathrm{~kg}$ or yoghurt - $7.3 \mathrm{PLN} / \mathrm{l}$. Higher expenditures per $\mathrm{kg}$ or litre of product may indicate that these households would purchase higher quality or more processed food.

Analysing the expenses for bread, it can be stated that pensioners and retired people are those who pay the most for it, over PLN 21.6. In the case of these groups, there was also the highest increase in spending on these products. In households of pensioners, expenditure on bread increased by almost $18.5 \%$ in relation to 2006 . Such high expenses were dictated by the large amount of bread consumed by them. In 2006, a pensioner used to consume monthly almost $6.6 \mathrm{~kg}$ of bread, and despite a significant reduction in its consumption, which took place in last 10 years, in 2016 it amounted to $4.4 \mathrm{~kg}$ and was comparable to the consumption in the households of farmers.

In the analysed years, the lowest expenses for bread were borne by the self-employed. In 2016, expenditures for this purpose in this group of households amounted to PLN 15.5 per person per month. In these households, the lowest increase in the expenditure for this purpose was observed as compared to 2006, as it did not exceed $8.1 \%$ Such low expenses for bread in this socio-economic group were related to its low consumption, which in 2016 amounted only to $2.8 \mathrm{~kg} /$ person and in comparison to 2006 it decreased by over $38.6 \%$.

\section{Conclusion}

In households in Poland there were changes in the demand for food products. The years 2000-2016 characterized with favourable conditions for the consumption in households. This was influenced by the favourable layout of economic factors that ensure the consumption, i.e. disposable income, product prices and consumer preferences.

Household disposable income per person in the analysed years increased on average by $5.4 \%$ each year. The increase in household income certainly contributed to the increase in demand for goods and services, but also caused changes in the structure of expenses. 
With the increase in incomes, the share of expenditure on food in total expenditure decreased, which is confirmed by the Engel's law. The increase in household income contributed to an increase in both total expenditure and expenditure for food products. However, the growth rate of expenditures in households was significantly lower than the rate of income growth. Real expenditures in the analyzed period increased on average annual basis at the rate of $1.04 \%$, while expenditures for food products by $1.02 \%$. A lower rate of expenditure growth in relation to income may be the result of the bolt effect, which assumes that households, despite the increase or decrease in income, keep spending at a similar level for some time, as they are accustomed to specific purchasing behaviours. Higher expenditures or their reduction, if the income was reduced in the case of households are gradual in nature. Increasing income is also visible in growing household savings.

Along with the increase in income, the amount of food products consumed did not increase significantly. In many cases, a declining trend was seen in households. This may indicate a qualitative change. Households increase the consumption of more expensive products, i.e. higher quality and more processed ones. Therefore, they give up the consumption of cheap, unprocessed or lower quality products. This was evident, for example, in the case of consumption of milk or eggs. In the analysed period, the growing consumption trend of yoghurt and cheese was visible in households, while the downward trend related to milk consumption.

Changes in the purchased products could be dictated by the changing needs and preferences of consumers. Higher earnings mean more time spent outside home. Long time spent at work results in the fact that these households (i.e. employees or self-employed) more often decide for the purchase of highly processed products or consumption of meals in catering establishments, unlike pensioners, retired persons or farmers having either more free time allowing them to prepare meals and harvest from their own gardens, or a place of residence in which there are no catering establishments.

The above analysis shows general trends in changes in demand for food products among households in Poland. The discussed issue should be subjected to a deeper analysis taking into account such variables as: financial situation, place of residence, age or number of members in the household, one may also include in the analysis the consumption of a larger number of products, especially those highly processed (as they are increasingly bought and consumed in households) and consumption of meals outside the places of residence.

\section{Bibliography}

Allais, O., Bertail, P., Nichele, V. (2010). The effects of a fat tax on French households' purchases: a nutritional approach. American Journal of Agricultural Economics, 92, 228-245.

Andreyeva, T., Chaloupka, F.J., Brownell, K.D. (2011). Estimating the potential of taxes on sugar-sweetened beverages to reduce consumption and generate revenue. Preventive Medicine, 52, 413-416.

Blisard, N., Biing-hwan, L., Cromartie, J., Ballenger, N. (2002). America's changing appetite: Food consumption and spending to 2020. Economics Research Service USDA, Food Review, 25(1), 2-9.

Budżety gospodarstw domowych w 2006-2016 (Household Budget Survey in 2000-2016). (2007 - 2017), GUS, Warszawa.

Bywalec, C., Rudnicki, L. (1999). Podstawy ekonomiki konsumpcji (Introduction to consumption economics). Wyd. AE, Kraków. 
Bywalec, Cz. (2010). Konsumpcja a rozwój gospodarczy, społeczny (Consumption and economic, social development). C.H. Beck, Warszawa.

Cromartie, J. (2002). Population Growth and demographic change 1980-2020. Economics Research Service USDA, Food Review, 25 (1), 10-13.

Dharmasena, S., Capps, O. (2011). Intended and unintended consequences of a proposed national tax on sugarsweetened beverages to combat the US obesity problem. Health Economics, 21, 669-694.

Goryńska-Goldmann, E, Ratajczak, P. (2010). Świadomość żywieniowa konsumenta a zachowania żywieniowe, (Nutritional awareness and nutritional behaviours of consumers), Journal of Agribusiness and Rural Development, 4(18), 41-48.

Green, R., Cornelsen, L., Dangour, A.D., Shankar, B., Mazzocchi, M., Smith, R.D. (2013). The effect of rising food prices on food consumption: systematic review with meta-regression. $B M J, 346, f 3703$

Holt, E. (2011). Hungary to introduce broad range of fat taxes. Lance, 378, 755.

Kearney, J. (2010). Food consumption trends and drivers. Philosophical Transactions of the Royal Society of London. Series B, Biological Sciences, 365, 2793-2807.

Laskowski, W. (2008). Zmiany poziomu spożycia żywności w Polsce (The changes of the level of food consumption in Poland). ZN SGGW Ekonomika i Organizacja Gospodarki Żywnościowej, 67, 5-14.

Mytton, O., Gray, A., Rayner, M., Rutter, H. (2007). Could targeted food taxes improve health? Journal Epidemiology and Community Health, 61, 689-694.

Regmi, A. (2001). Changing structure of global food consumption and trade: an introduction. Economics Research Service, USDA Agricultural and Trade Report WRS-01-1.

Rocznik Statystyczny Rzeczpospolitej Polskiej 2001-2017 (Statistical Yearbook of the Republic of Poland 2001-2017). (2001-2017), GUS, Warszawa.

Senauer, B. (2001). The food consumer in the XXI century. New Research Perspectives. Department of Applied Economics, University of Minnesota.

Smed, S. (2012). Financial penalties on foods: the fat tax in Denmark. Nutrition Bulletin, 37, 142-147.

Świetlik, K. (2015). Konsumpcja żywności w Polsce w minionej dekadzie. Uwarunkowania i tendencje (Consumption of Foodstuffs in Poland in the Past Decade. Determinants and Tendencies). Handel Wewnętrzny, 5(358), 347-363.

Sytuacja gospodarstw domowych w 2016 r. w świetle wyników badania budżetów gospodarstw domowych. Notatka informacyjna (The situation of households in 2016 in the light of the results of the household budget survey. Information note). (2017), GUS, Warszawa. Available 22.02.2018 from: https://stat.gov.pl/obszarytematyczne/warunki-zycia/dochody-wydatki-i-warunki-zycia-ludnosci/sytuacja-gospodarstw-domowych-w2016-r-w-swietle-wynikow-badania-budzetow-gospodarstw-domowych,3,16.html.

Urban, S., Tarnowska, A. (2012). Statystyczna ocena zmian w spożyciu żywności na podstawie badań budżetów gospodarstw domowych (Statistical evaluation of changes in food consumption based on household budget surveys). RN SERiA, 14(8), 151-158.

Varela-Moreiras, G., Ávila, J.M., Cuadrado, C., del Pozo, S., Ruiz, E., Moreiras, O. (2010). Evaluation of food consumption and dietary patterns in Spain by the Food Consumption Survey: updated information. European Journal of Clinical Nutrition, 64, S37-S43.

Whitton, C., Nicholson, S.K., Roberts, C., Prynne, C.J., Pot, G.K., Olson, A., Fitt, E., Cole, D., Teucher, B., Bates, B., Henderson, H., Pigott, S., Deverill, C., Swan, G., Stephen, A.M. (2011). National diet and nutrition survey: UK food consumption and nutrient intakes from the first year of the rolling programme and comparisons with previous surveys. British Journal of Nutrition, 106, 1899-1914.

Zalega, T. (2008). Mikroekonomia (Microeconomics). Wyd. Nauk. Wydziału Zarządzania UW, Warszawa. Available 10.05.2018 from: www.rynekzdrowia.pl/Uslugi-medyczne/W-Polsce-nadwage-lub-otylosc-majuz-64-proc-mezczyzn-i-49-proc-kobiet,177695,8,1.html.

\section{For citation:}

Kowalska A. (2018). Changes in Demand and Expenses for Food in Households in Poland. Problems of World Agriculture, 18(2), 166-174; DOI: 10.22630/PRS.2018.18.2.44 